\title{
PHILOSOPHICAL BASIS ON EDUCATION PRINCIPLE OF TAMANSISWA IN THE BEGINNING OF ITS ESTABLISHMENT
}

\author{
Bonifasia Ekta Fima Natalia \\ STIE Solusi Bisnis Indonesia \\ Email: ekta.fima@gmail.com
}

\begin{abstract}
This research aims to find the philosophical foundation of the article "Principles of Education of Tamansiswa at the Beginning of Its Establishment" in the book of "Ki Hajar Dewantara's Thought and Struggle" which is published by The National Awakening Museum of the Directorate General of Culture Ministry. This book consists of six parts, which discusses about some topics related to KHD. The researcher chose the second part to be analyzed because it discusses the teachings of KHD which is interesting and is relevant in recent education. The research method uses inferential content analysis. The researcher comprehend and interpret the symbolic message in the article. The research procedure used are the procurement of data, data reduction, inference, and data analysis. Construct analysis is done using qualitative approach with conceptual domain. Data validity was measured by using semantic validity and test retest reliability. The research result shows that there are philosophical basis on education principles of Tamansiswa, philosophy of essentialism and humanism, which is values issued in cultural or social heritage that have existed since human civilization, for example in the among systems and trilogy leadership slogan Ing Ngarso Sung Tulodho, Ing Madyo Mangun Karso and Tut Wuri Handayani implemented in Tamansiswa education.
\end{abstract}

Keywords: philosophical basis, education principles, KHD's teaching

\section{INTRODUCTION}

Education in Indonesia is inseparable from the influence of the father of Indonesian education Ki Hajar Dewantara (KHD). Tamansiswa is a college that was founded by Ki Hajar Dewantara which contains educational principles that prioritize young people. The principles of Tamansiswa education are still relevant to use today. Ki Hajar Dewantara stated that education is a means of political mobilization and at the same time as the welfare of the people. From education will result in the leadership of the nation's people who will lead the people and invite them to get an even education, an education that can be enjoyed by all Indonesian people (Wiryopranoto, 2017).

According to Ki Hadjar Dewantara, education is an effort to advance the growth of character (inner strength, character), mind (intellect) and body of the child, in the framework of perfection of life and harmony of all humans across the world. (Dewantara, 1962: 14-15).

The world of education in entering the industrial era 4.0 experienced many changes. Education-related policies were prepared based on demands for graduate competencies who understand technology developments. The development of technology then changed the way of pragmatism and changed the way of the public about education with various 
achievements. However, on a different side, people are starting to be educated, so that there are people who are now questioning the values of noble character as the basis for the development of character education that is reduced.

The objective of National Education based on Pancasila and Constitution Number 20 of 2003 is to develop capabilities and shape the character and civilization of a dignified nation in the context of educating the life of the nation, aiming to develop the potential of students to become human beings who believe and fear God Almighty, noble, healthy, knowledgeable, capable, creative, independent, and become citizens who are democratic and responsible.

Education has a very important role in the whole of human life. Education core consists of interactions between humans, especially between educators and learners in order to achieve educational goals. In the interaction involved the contents of the interaction and the process of how the interaction took place.

Education is a community life event, in which includes aspects of communication, material, technology, values, and human development itself (Suyitno, 2009). The study of education not only discusses the physical aspects of humans, but also aspects of the spiritual aspects. Educational assumptions or foundation will serve as a starting point or foundation for teachers in implementing educational practices. Considering the nature of education which is humanization, it is an effort to humanize humans, educators need to understand the nature of human beings as one of its foundations. The concept of human nature adopted by educators will have implications for the concept and practice of education.

\section{RESEARCH METHOD}

The design of this research is inferential content analysis research. In content analysis, text search is more than just theoretical and methodological studies, content analysis is at the same time utilizing the source of the literature as study material. Content analysis is a research technique for making inferences that can be replicated (authentic) and validated by observing the context of the data (Krippendorf, 1991). The focus of this research lies in the content of character education in principles of Tamansiswa Teachings created by KHD. This study will answer the fundamental philosophical problem of education in priciples of Tamansiswa. Data collection techniques in the form of article texts are supported by theories that are relevant to researchers as the main instrument (Zuchdi, 2019). The validity of the data used is semantic validity, which aims to present 
the information contained in the data analyzed in the context of educational philosophy. Analytical constructs are made to identify, evaluate and examine data using standards used to compare the results of research (Zuchdi and Afifah, 2019). Text data analyzed in this study are in the form of an article entitled "Principles of Tamansiswa Education at the Beginning of Its Establishment" written by Djoko Marihandono in a book entitled "Thought and Struggle of Ki Hajar Dewantara" published by the National Awakening Museum of the Directorate General of Culture Ministry of Culture. Strauss and Corbin in Zuchdi and Afifah (2019) suggest the use of analytical tools, which are thinking techniques used by researchers to facilitate coding.

\section{RESULT AND DISCUSSION}

Tamansiswa, which stands for Tamansiswa National Movement, which is an educational institution founded by Ki Hajar Dewantara in July 1922 in Yogyakarta. On January 6, 1923 the Tamansiswa National Movement was declared a "free endowment". This institution was handed over by Ki Hadjar Dewantara on August 7, 1930 to the Tamansiswa Foundation, based in Yogyakarta. Tamansiswa School emerged as a "national education college".

Ki Hajar Dewantara's real name is RM Soewardi Soerjaningrat, since establishing Tamansiswa changed his name to Ki Hajar Dewantara to be more modest and able to blend in with the indigenous community. During the Dutch colonial period, the right to education was only for the Dutch or the elite, priyayi or noble, including RM Soewardi Soerjaningrat, who was the son of GPH Soerjaningrat and grandchildren of Pakualam III. By establishing Tamansiswa, Ki Hajar Dewantara wanted to provide opportunities for the aboriginal people to be able to obtain the right to education as did the nobility and the Dutch people. Ki Hajar Dewantara fought for Indonesian independence through education.

In his article, Marihandono (2017) explains that the principles of Tamansiswa education are (1) the right to self-determination; (2) independent students; (3) education that enlightens the community; (4) education must cover a wide area; (5) struggle demands independence; (6) self-defense system; and (7) children's education.

Tamansiswa's educational principles are based on the philosophy of essentialism. Essentialism considers education to be based on values embedded in the cultural or social heritage that has existed since human civilization. Ki Hajar Dewantara's teaching is that students must respect the nation's cultural heritage. In Tamansiswa education, cultural heritage is taught through language, history, morals, music, dance and so on 
(Marihandono, 2017). At Tamansiswa College, mother tongue is used as the language of instruction. With the use of mother tongue as an introduction to education that will have an impact on carrying out religious worship, the elimination of games and songs of Dutch children and replace them with a national model. If there is no pure mother tongue, (as in Batavia, for example), a new Malay language called Indonesian is used as an introduction. Mastery of the people's own language becomes the first condition because only then can the people feel their own culture. If education goes well, cultural transfer will inevitably occur (Marihandono, 2017).

The philosophy of humanism also underpins Tamansiswa education. This institution rejects the notion of "teaching" in the sense of "intentional formation of the character of children" with three terms "government - obedient - orderly". The teaching method adopted requires comprehensive attention which is a condition for self-development for the development of character, body and soul of children. This attention is referred to as the "system of circles" (Marihandono, 2017). The "among" system concept is to educate, guard and guide lovingly. In the Ki Hajar Dewantara's concept, how to educate with orders, coercion and punishment will be replaced with guidance and support for children in the education process. An educator or teacher will draw closer to the natural environment and society that will make children think positively.

In the among system, the teacher gives guidance, but by still giving freedom to students in accordance with the natural code of the students. Students have independence in the education process so that students can grow into creative and critical individuals.

The among system that being proposed had the meaning that children would grow freely. Tut Wuri Handayani mandate must mean to follow and influence so that foster children can walk in a good direction. With this among systems, it is free for children to develop their talents and students always find their own way without waiting for orders from their superiors.

Tamansiswa has a leadership trilogy slogan implemented by Ki Hajar Dewantara namely Ing Ngarso Sung Tulodho, Ing Madyo Mangun Karso and Tut Wuri Handayani. Ing Ngarso Sung Tulodho has the understanding that an educator should be able to stand in the front as a leader who sets an example, role model or role model. The easiest way to lead an army is to set an example and the easiest way to set an example is to practice what you preach. Ing Madyo Mangun Karso means an educator should be able to position himself among his students as friends who encourage, inspire interest, build intention. By walking together in the midst of students, an educator knows very well what is happening 
during the education process and understands how students feel. For example, when students fall or experience obstacles, educators can encourage them to get back on their feet. Whereas Tut Wuri Handayani means an educator must also be able to stand behind and encourage his students. Moral encouragement and motivation is very necessary for students to keep going forward and not give up. The motto of Tut Wuri Handayani is the behavior of the tutor or teacher who is freeing students to do something in accordance with their desires and desires, as long as it is still in accordance with reasonable norms and does not harm anyone.

By applying the trilogy of leadership, an educator must be able to be an example, encouraging and motivating his students. Ki Hajar Dewantara's motto is phenomenal in the world of education and is the pride of the Indonesian people in the world. Some countries even adopted this teaching. Although the concept of leadership trilogy was raised in the $19^{\text {th }}$ century, it is still up to date to be applied today.

\section{CONCLUSION}

The teachings of the father of national education, Ki Hajar Dewantara, had a profound impact on Indonesia's education. The principles of education that he coined and applied in Tamansiswa colleges are the right to self-determination, independent students, education that enlightens the community, education must cover a wide area, the struggle for independence, self-defense system, and children's education. The right to selfdetermination takes into account the demands of togetherness from a harmonious society, not dependent on other people or other groups. This is in line with the National Education Goals based on Pancasila and Constitution Number 20 Year 2003, to develop the potential of students to become people of faith and to fear God Almighty, have good morality, be healthy, have good knowledge, be capable, capable, creative, independent, and become democratic and responsible citizens.

The philosophical basis that underlies the principles of Tamansiswa education is the philosophy of essentialism, where essentialism views education as having to stand on values embedded in cultural or social heritage that have existed since human civilization. Ki Hajar Dewantara was proud to promote Indonesian culture even though at that time Indonesia was under Dutch colonialism. Education is only the right of the elite or the nobility. In Tamansiswa colleges, educators play a role as tutors that is someone who educates, guides and sets an example. This system is known as the system among, where educators provide freedom for their students to develop. At Tamansiswa College, the 
trilogy of leadership applied by Ki Hajar Dewantara was also implemented, namely Ing Ngarso Sung Tulodho, Ing Madyo Mangun Karso and Tut Wuri Handayani. The concept of education requires an educator to be able to have three roles, namely standing in front as a leader who provides an example for their students, standing in the middle of the students as a friend for them who encourage, and standing behind giving encouragement to their students. If this concept is applied, then an ideal education is achieved that realizes independent, creative and critical students.

\section{REFERENCES}

Arsip Taman Siswo koleksi B21A dan B21 B National Collection Archief Nederland and the National Archives of the Republic of Indonesia.

Cresswell, J. W. 2014. Research Design: Qualitative, Quantitative, and Mixed Method Approaches ( $4^{\text {th }}$ Ed.). Thousand Oaks, CA: Sage Publication.

Krippendorff, K. 1991. Content Analysis: an introduction on its Methodology. London: SAGE Publications.

Marihandono, D. 2017. Prinsip Pendidikan Taman Siswa Pada Awal Pendiriannya. Jakarta: Museum Kebangkitan Nasional Direktorat Jenderal Kebudayaan Kementerian Kebudayaan.

Pidarta, Made. 1997. Landasan Kependidikan. Jakarta : Rineka Cipta.

Retnaningsih, R., Yustika \& Iryayo, M. 2018. Reflection on the Among System for Character Building in the Hermeneutic Perspective. Yogyakarta: Proceeding International Seminar Evaluation of Instruction and Learning Outcome Universitas Sarjanawiyata Tamansiswa - Indonesia, 10th November 2018.

Siswoyo, D. 2008. Ilmu Pendidikan. Fakultas Ilmu Pendidikan, Universitas Negeri Yogyakarta. Yogyakarta: UNY Press.

Susanto, M. R. \& Retnaningsih, R. 2018. Melacak Pemikiran Avant Garde Ki Hadjar Dewantara Melalui Konsep Pendidikan Nasional Sebagai Fenomena Quantum Leap Dalam Perspektif Filsafat Organisme. Yogyakarta: Prosiding Seminar Nasional Pendidikan.

Suyitno. 2009. Landasan Filosofis Pendidikan. Bandung: Universitas Pendidikan Indonesia.

Wiryopranoto, S., and Herlina, Nina and Marihandono, D., and Tangkilisan, Y. B. 2017. Ki Hajar Dewantara: Pemikiran dan perjuangannya. Museum Kebangkitan Nasional, Jakarta. ISBN 9786026155207.

Zuchdi, D. 1993. Panduan Penelitian Analisis Konten Yogyakarta: Lembaga Penelitian IKIP Yogyakarta. 
Zuchdi, D. and Afifah, W. 2019. Analisis Konten Etnografi \& Grounded Theory dan Hermeneutika dalam Penelitian. Jakarta: Bumi Aksara. 